\title{
Modulation of quaternary structure and enhancement of ligand binding by the K-turn of tandem glycine riboswitches
}

\author{
NATHAN J. BAIRD and ADRIAN R. FERRÉ-D'AMARÉ ${ }^{1}$ \\ National Heart, Lung, and Blood Institute, National Institutes of Health, Bethesda, Maryland 20892-8012, USA
}

\begin{abstract}
Most known glycine riboswitches have two homologous aptamer domains arranged in tandem and separated by a short linker. The two aptamers associate through reciprocal "quaternary" interactions that have been proposed to result in cooperative glycine binding. Recently, the interaptamer linker was found to form helix P0 with a previously unrecognized segment $5^{\prime}$ to the first aptamer domain. P0 was shown to increase glycine affinity, abolish cooperativity, and conform to the K-turn motif consensus. We examine the global thermodynamic and structural role of P0 using isothermal titration calorimetry (ITC) and small-angle X-ray scattering (SAXS), respectively. To evaluate the generality of P0 function, we prepared glycine riboswitch constructs lacking and including P0 from Bacillus subtilis, Fusobacterium nucleatum, and Vibrio cholerae. We find that P0 indeed folds into a K-turn, supports partial pre-folding of all three glycine-free RNAs, and is required for ITC observation of glycine binding under physiologic $\mathrm{Mg}^{2+}$ concentrations. Except for the unusually small riboswitch from $F$. nucleatum, the K-turn is needed for maximally compacting the glycine-bound states of the RNAs. Formation of a ribonucleoprotein complex between the $B$. subtilis or the $F$. nucleatum RNA constructs and the bacterial K-turn binding protein YbxF promotes additional folding of the free riboswitch, and enhances glycine binding. Consistent with the previously reported loss of cooperativity, P0-containing $B$. subtilis and $V$. cholerae tandem aptamers bound no more than one glycine molecule per riboswitch. Our results indicate that the P0 K-turn helps organize the quaternary structure of tandem glycine riboswitches, thereby facilitating ligand binding under physiologic conditions.
\end{abstract}

Keywords: quaternary structure; K-turn; RNA aptamers; ribonucleoprotein complex; SAXS

\section{INTRODUCTION}

The glycine riboswitch was first described by Mandal et al. (2004), who noted two remarkable characteristics of this bacterial gene-regulatory mRNA domain. First, most known examples of this riboswitch are comprised of two homologous tandem glycine-binding aptamer domains separated by a short linker, and upstream of a single element that interfaces with the gene expression machinery (i.e., a single expression platform). Second, in vitro analysis of glycine binding by an RNA construct comprised of two aptamer domains (derived from the $5^{\prime}$-untranslated region of the gcvT mRNA of Vibrio cholerae; this construct is hereafter referred to as VcI-II) suggested the presence of cooperativity, with a Hill coefficient of 1.64. In contrast, the isolated second aptamer domain from the same mRNA (VcII) bound to glycine with a Hill coefficient of 0.97 . Cooperativity appears to arise from interaction of the two aptamer domains in a manner analogous to cooperative ligand binding through quaternary structure formation in oligomeric proteins (Monod et al. 1965). Among

\footnotetext{
${ }^{1}$ Corresponding author

E-mail adrian.ferre@nih.gov

Article published online ahead of print. Article and publication date are at http://www.rnajournal.org/cgi/doi/10.1261/rna.036269.112.
}

known riboswitch classes, the presence of tandem aptamer domains preceding a single-expression platform is unusual. Three additional examples have been documented for guanine-ykkC, cyclic di-GMP, and glutamine aptamers (Sudarsan et al. 2006, 2008; Ames and Breaker 2011), but only glycine riboswitches generically occur as tandem aptamers with a single expression platform. For other tandem riboswitches known, an expression platform follows each aptamer domain (Sudarsan et al. 2006; Welz and Breaker 2007). Crystallographic structure determination demonstrates that isolated glycine riboswitch aptamer domains adopt the same fold as in tandem (Huang et al. 2010; Butler et al. 2011). Moreover, both in solution and in crystals, the isolated aptamer domains show a propensity to oligomerize, utilizing what appears to be the same interface as that used by the tandem aptamers when present in a single RNA chain (Huang et al. 2010; Butler et al. 2011; Erion and Strobel 2011).

Biochemical analysis of ligand binding by the glycine riboswitch demonstrated a requirement for $\mathrm{Mg}^{2+}$ concentrations of 20-100 mM, significantly above the $<5 \mathrm{mM}$ concentrations considered physiologic (Alatossava et al. 1985; Romani and Scarpa 1992). In particular, isothermal titration calorimetry (ITC) could detect evidence of glycine binding only above $20 \mathrm{mM} \mathrm{Mg}^{2+}$ concentration $\left(K_{\mathrm{d}} \sim 30 \mu \mathrm{M}\right.$ and $\sim 3 \mu \mathrm{M}$ 
for glycine binding to the isolated $V c I$ and $V c$ II aptamer domains, respectively). Recently, two groups have independently provided a possible explanation for the unusually high divalent cation requirement of this RNA. Kladwang et al. (2012) and Sherman et al. (2012) found that the linker segment connecting the two aptamer domains, rather than being single-stranded, forms a hitherto unrecognized helix (P0 hereafter) with a conserved RNA segment $5^{\prime}$ to the first aptamer domain (Fig. 1A). These groups analyzed glycine binding using chemical probing (DMS, SHAPE, and in-line probing), and found that inclusion of $\mathrm{P} 0$ resulted in up to 120-fold tighter glycine binding. Remarkably, Sherman et al. (2012) found that VcI-II constructs that include P0 not only bind glycine with higher affinity, but no longer show evidence of cooperativity. Kladwang et al. (2012) and Sherman et al. (2012) noted that for at least 50\% of known tandem glycine riboswitches, the sequences of the $\mathrm{P} 0$ helices conform to a K-turn consensus (Fig. 1A). The K-turn is an RNA structural motif comprised of two helices flanking a bulge. The motif causes the helical path to bend by $\sim 120^{\circ}$ and is often the binding site for proteins (Klein et al. 2001). $\mathrm{K}$-turns are present in several riboswitch classes, including the Class-I S-adenosylmethionine (SAM-I) and lysine riboswitches, where it has been shown that K-turn integrity is essential for productive folding and ligand recognition (Blouin and Lafontaine 2007; Heppell and Lafontaine 2008).

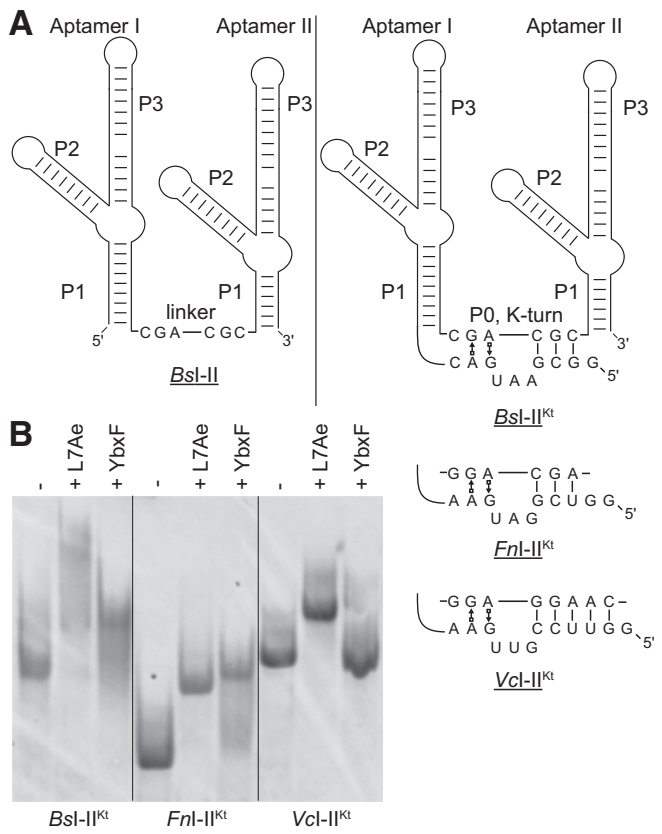

FIGURE 1. The P0 helix of glycine riboswitches is a K-turn. $(A)$ Tandem glycine riboswitch aptamers joined by a single-stranded linker, denoted I-II (left), and by the recently discovered (Kladwang et al. 2012; Sherman et al. 2012) K-turn, denoted I-II ${ }^{\mathrm{Kt}}$ (right). The sequence of the $\mathrm{K}$-turn is given for each of the three $\mathrm{I}-\mathrm{II}^{\mathrm{Kt}}$ examined. (B) EMSA analysis of three $\mathrm{I}-\mathrm{II}^{\mathrm{Kt}}$ constructs using the L7Ae and YbxF K-turn binding proteins.
Kladwang et al. (2012) and Sherman et al. (2012) analyzed the effect that the presence of $\mathrm{P} 0$ has on the glycine riboswitch at the local, single-nucleotide level through chemical probing techniques. Because formation of a K-turn in $\mathrm{P} 0$ might exert its biological function by orienting the two aptamer domains and facilitating their interaction, we hypothesized that there should be a global structural change that results from inclusion of $\mathrm{P} 0$ in a glycine riboswitch RNA. Moreover, the K-turn might facilitate glycine binding at lower, physiologic $\mathrm{Mg}^{2+}$ concentrations. To evaluate this, we have now performed ITC and small-angle X-ray scattering (SAXS) analyses of glycine riboswitch constructs with and without the P0 K-turn (denoted I-II ${ }^{\mathrm{Kt}}$ and I-II, respectively) in the presence of physiologic divalent cation concentrations. To examine the generality of the function of the P0 K-turn, we studied three previously well-characterized tandem glycine riboswitches from $V$. cholerae $(V c)$, Bacillus subtilis (Bs), and Fusobacterium nucleatum (Fn). We find that the $\mathrm{K}$-turn is required for detection of glycine binding by ITC in $5 \mathrm{mM} \mathrm{Mg}^{2+}$. Even in the absence of glycine, the K-turn facilitates global folding of the RNAs. In two of the three I-II ${ }^{\mathrm{Kt}}$ constructs, inclusion of the K-turn results in a more compact glycine-bound conformation relative to the construct lacking the K-turn. In addition, when the K-turn is bound specifically by the bacterial protein YbxF, a modest increase in glycine-binding affinity and additional compaction of the glycine-free RNA results. We conclude that the P0 K-turn is necessary for tandem glycine riboswitches to achieve their native (most compact) glycine-bound structures under physiologic conditions.

\section{RESULTS}

\section{The P0 helix is a canonical K-turn}

The sequences of $\mathrm{P} 0$ in the V. cholerae, B. subtilis, and F. nucleatum glycine riboswitches (Fig. 1A) are consistent with a K-turn motif (Kladwang et al. 2012; Sherman et al. 2012). Because of its RNA-binding specificity and high affinity, the K-turn-binding protein L7Ae has previously been used to demonstrate that RNA sequences fold into this structural motif (Schroeder et al. 2010). We used L7Ae from the archaeon Methanococcus janaschii and the homologous YbxF from the bacterium B. subtilis in electrophoretic mobility shift assays (EMSA) with the three $\mathrm{I}-\mathrm{II}^{\mathrm{Kt}}$ constructs to demonstrate that their P0 helices indeed fold into K-turns. Each of the RNAs exhibited a gel mobility shift in the presence of L7Ae (Fig. 1B). In the presence of YbxF, only the $B s \mathrm{I}-\mathrm{II}^{\mathrm{Kt}}$ and $\mathrm{Fn} \mathrm{I}-\mathrm{II}^{\mathrm{Kt}}$ RNAs were shifted. That $\mathrm{YbxF}$ does not bind all three $\mathrm{I}-\mathrm{II}{ }^{\mathrm{Kt}} \mathrm{RNAs}$ is consistent with our previous finding that $\mathrm{YbxF}$ is more selective regarding the K-turn motifs that it binds than L7Ae (Baird et al. 2012). ITC experiments (see below) are consistent with the binding pattern observed by EMSA for these three tandem glycine riboswitch constructs. 


\section{K-turn containing glycine riboswitches fold at physiologic $\mathrm{Mg}^{2+}$ concentration}

Most structured RNAs require divalent metal ions to fold (for review, see Woodson 2005). In addition to folding, the VcI-II RNA has specific metal ion requirements for glycine binding (Huang et al. 2010; Lipfert et al. 2010; Butler et al. 2011). Many previous studies of the VcI-II RNA utilized conditions containing divalent concentrations much higher than physiologic $\left(\geq 10 \mathrm{mM} \mathrm{Mg}^{2+}\right)$. For example, ITC studies of glycine binding to $V c$ I-II were performed in 20 and $40 \mathrm{mM} \mathrm{Mg} \mathrm{Mg}^{2+}$ (Huang et al. 2010). We examined the folding response of the three $\mathrm{I}-\mathrm{II}^{\mathrm{Kt}}$ constructs to $\mathrm{Mg}^{2+}$ by titrating the divalent cation into RNA samples in buffer containing $100 \mathrm{mM}$ $\mathrm{KCl}$ and monitored heat evolution by ITC. The response curves exhibited a transition between 3 and $4 \mathrm{mM} \mathrm{Mg}^{2+}$, after which the evolved heat monotonically decreased (Fig. 2A). Although this transition is at higher $\mathrm{Mg}^{2+}$ concentration than has been reported for the folding of other RNAs (e.g., $<1 \mathrm{mM}$ for B. subtilis RNase $\mathrm{P}$ specificity domain) (Baird et al. 2005), this probably is a result of the high concentrations $(\sim 50 \mu \mathrm{M})$ of RNA used in these RNA folding experiments. As much as several $\mathrm{mM} \mathrm{Mg}^{2+}$ would be expected to interact with the RNA backbone, reducing the activity of $\mathrm{Mg}^{2+}$ in solution. While the titration curves are not immediately interpretable as representing unfolded, intermediate or completely folded states, it appears that at concentrations in excess of 3-4 mM, the RNAs have folded beyond an initial transition. We therefore performed subsequent ITC experiments with samples pre-equilibrated in $5 \mathrm{mM} \mathrm{Mg}^{2+}$ and SAXS at various $\mathrm{Mg}^{2+}$ concentrations near $5 \mathrm{mM} \mathrm{Mg}^{2+}$.

\section{The K-turn is required for ITC detection of glycine binding in $5 \mathrm{mM} \mathrm{Mg}{ }^{2+}$}

The K-turn was reported to improve glycine-binding affinity in tandem aptamer constructs from V. cholerae, B. subtilis, and F. nucleatum (Kladwang et al. 2012; Sherman et al. 2012). We performed ITC analyses for V. cholerae and B. subtilis I-II and I-II ${ }^{\mathrm{Kt}}$ constructs under near-physiologic conditions to evaluate thermodynamically the contribution of the K-turn. In $5 \mathrm{mM} \mathrm{Mg}^{2+}$ and $20^{\circ} \mathrm{C}$, no heat was evolved upon titration of glycine into VcI-II (Fig. 2B). This contrasts with the exothermic binding previously reported in $40 \mathrm{mM}$ $\mathrm{Mg}^{2+}$ at $35^{\circ} \mathrm{C}$ (Huang et al. 2010). Thus, glycine binding by this RNA is sensitive to both temperature and divalent metal ion concentration. The $V c \mathrm{I}-\mathrm{II}^{\mathrm{Kt}} \mathrm{RNA}$ was reported to bind glycine nearly 12 -fold tighter than $V c$ I-II in $20 \mathrm{mM} \mathrm{Mg}^{2+}$ (Sherman et al. 2012). Under our conditions, VcI-II ${ }^{\mathrm{Kt}}$ exhibited a reproducible ITC response to glycine. The binding isotherm is endothermic; thus, the reaction is entropically driven (Fig. 2B). The shape of the isotherm is not a simple sigmoid; there appears to be a monotonic decrease in heat evolved over the concentration tested (Materials and Methods). Fitting the data as a single-site binding yields a dissociation constant, $K_{\mathrm{d}}$, of $4.3 \pm 0.75 \mu \mathrm{M}$ and binding stoichiometry, $n$, of $1.05 \pm 0.08$ (Table 1). This $K_{\mathrm{d}}$ is similar to that observed by in-line probing in $20 \mathrm{mM} \mathrm{Mg}^{2+}$ (Sherman et al. 2012); the affinity for glycine of this RNA appears to be insensitive to changes in $\mathrm{Mg}^{2+}$ concentration between 5 and $20 \mathrm{mM}$.

In $5 \mathrm{mM} \mathrm{Mg}^{2+}$, the minimal B. subtilis tandem glycine aptamer construct (BsI-II) did not yield an ITC binding isotherm (Fig. 2C), whereas BsI-II ${ }^{\mathrm{Kt}}$ did. The overall shape of the isotherm was similar to that observed for $V c \mathrm{I}-\mathrm{II}^{\mathrm{Kt}}$ (Fig. $2 \mathrm{~B})$. The $K_{\mathrm{d}}$ for the BsI-II ${ }^{\mathrm{Kt}}$-glycine complex is $15.3 \mu \mathrm{M}$ (Table 1), about fourfold weaker than reported by in-line probing in $20 \mathrm{mM} \mathrm{Mg}^{2+}$ (Sherman et al. 2012). Given the identical enthalpy and entropy of glycine binding by BsI$\mathrm{II}^{\mathrm{Kt}}$ and $V c \mathrm{I}-\mathrm{II}^{\mathrm{Kt}}(\Delta H \sim 6 \mathrm{kcal} / \mathrm{mol}$ and $T \Delta S \sim 12 \mathrm{kcal} / \mathrm{mol})$ (Table 1), their different $K_{\mathrm{d}}$ 's must arise from differences in stoichiometry. BsI-II ${ }^{\mathrm{Kt}}$ binds glycine with an apparent molar ratio of $0.75: 1$ (glycine:RNA). This subunity value for $n$ is consistent with that recently reported (Sherman et al.
A

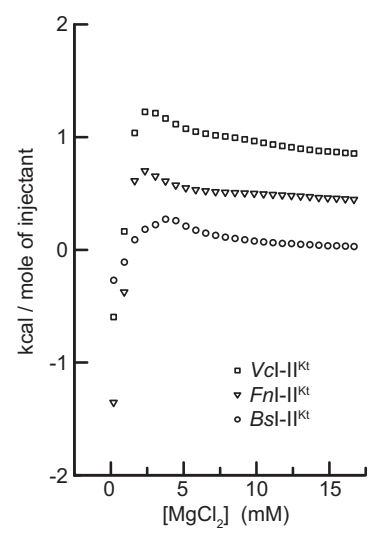

B

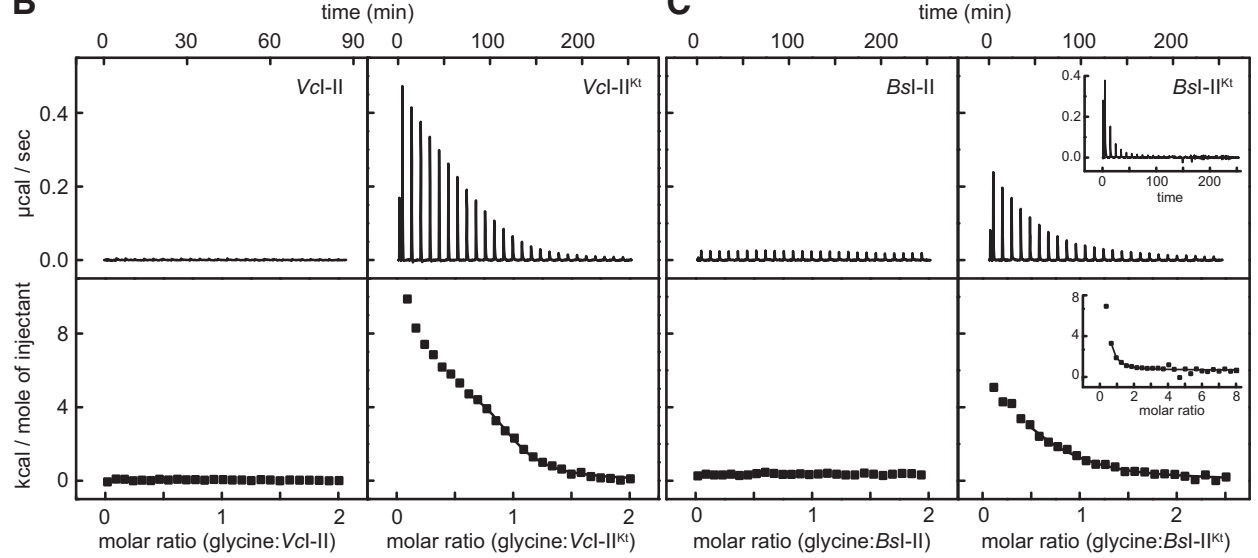

FIGURE 2. ITC analyses of RNA folding and glycine binding. (A) $\mathrm{Mg}^{2+}$ titration of the three $\mathrm{I}-\mathrm{II}^{\mathrm{Kt}}$ RNAs used in this study. For clarity, data for FnI$\mathrm{II}^{\mathrm{Kt}}$ and $V c \mathrm{I}-\mathrm{II}^{\mathrm{Kt}}$ are offset by $0.4 \mathrm{kcal} / \mathrm{mol}$ and $0.8 \mathrm{kcal} / \mathrm{mol}$, respectively, in this panel only. (B) ITC titrations of glycine into $V c \mathrm{I}-\mathrm{II}(l e f t)$ and $V c \mathrm{I}-\mathrm{II}{ }^{\mathrm{Kt}}$ (right) in $5 \mathrm{mM} \mathrm{Mg}^{2+}$. (C) ITC titrations of glycine into BsI-II (left) and $B s \mathrm{I}-\mathrm{II}^{\mathrm{Kt}}$ (right) in $5 \mathrm{mM} \mathrm{Mg}^{2+}$, including a titration in which the final molar ratio (glycine:RNA) in the solution is $>8$ (inset). 
TABLE 1. Thermodynamic parameters for $V$. cholerae and B. subtilis tandem aptamers

\begin{tabular}{|c|c|c|c|c|c|}
\hline & VCl-II & $V_{C l}-I^{K t}$ & $B s \mid-I I$ & $B s \mathrm{I}-\mathrm{II}^{\mathrm{Kt}}$ & $B s \mathrm{I}-\mathrm{II}^{\mathrm{Kt}}+\mathrm{YbxF}$ \\
\hline$n$ & No heat & $1.05 \pm 0.08$ & No heat & $0.76 \pm 0.09$ & $0.55 \pm 0.01$ \\
\hline$K_{\mathrm{d}}(\mu \mathrm{M})$ & detected & $4.3 \pm 0.75$ & detected & $15.3 \pm 1.5$ & $9.1 \pm 1.4$ \\
\hline$\Delta H(\mathrm{kcal} / \mathrm{mol})$ & & $6.0 \pm 0.3$ & & $6.0 \pm 1.0$ & $5.7 \pm 0.9$ \\
\hline$T \Delta S(\mathrm{kcal} / \mathrm{mol})$ & & $13.2 \pm 0.1$ & & $12.4 \pm 0.9$ & $12.5 \pm 0.8$ \\
\hline
\end{tabular}

K-turns often mediate long-range interactions in RNAs (Schroeder et al. 2011). The increased binding affinity we observed by ITC for $V c \mathrm{I}-\mathrm{II}^{\mathrm{Kt}}$ over $V c \mathrm{I}-$ II may reflect promotion of interaptamer ("quaternary") interactions by the $\mathrm{K}$ turn. To evaluate this, we compared the global size and shape of $V c I-I I$ and $V c I-$ $\mathrm{II}^{\mathrm{Kt}}$ by SAXS in solution at 5 and 10 $\mathrm{mM} \mathrm{Mg}^{2+}$. For $V c \mathrm{I}-\mathrm{II}$, our experiments

2012). No additional binding was observed by ITC even when the final molar ratio in solution exceeds 8 (Fig. 2C, inset).

\section{The cognate K-turn binding protein YbxF enhances glycine binding to $B s \mathrm{I}-\mathrm{II}^{\mathrm{Kt}}$}

K-turns can be stabilized by tertiary structure formation, increased $\mathrm{Mg}^{2+}$ concentrations, or by K-turn binding proteins (Schroeder et al. 2011). To test whether YbxF might improve glycine binding under physiologically relevant $\mathrm{Mg}^{2+}$ concentrations, we performed ITC as described above with the BsI$\mathrm{II}^{\mathrm{Kt}} \mathrm{RNA}$ and a 1.5-fold molar excess of B. subtilis $\mathrm{YbxF}$ in the sample cell. We found that the cognate ribonucleoprotein (RNP) complex binds glycine with $\sim 1.7$-fold higher affinity $\left(K_{\mathrm{d}} \sim 9 \mu \mathrm{M}\right)$ than the RNA alone at $5 \mathrm{mM} \mathrm{Mg}^{2+}$ (Table 1). We investigated whether the protein could stabilize BsI-II ${ }^{\mathrm{Kt}}$ at even lower $\mathrm{Mg}^{2+}$ concentrations and enhance glycine binding. At 1.5 and $2.5 \mathrm{mM} \mathrm{Mg}^{2+}$, no heat evolution was detected upon the addition of glycine to BsI-II ${ }^{\mathrm{Kt}}$ (data not shown). Interestingly, ITC experiments in which YbxF was titrated into $B s \mathrm{I}-\mathrm{II}^{\mathrm{Kt}}$ in $1 \mathrm{mM}$ and $5 \mathrm{mM} \mathrm{Mg}^{2+}$ exhibited diverging properties. The signal was strongly exothermic in $5 \mathrm{mM}$ $\mathrm{Mg}^{2+}$, but much weaker and endothermic in $1 \mathrm{mM} \mathrm{Mg}^{2+}$ (data not shown). Together, this suggests that $B s \mathrm{I}-\mathrm{II}^{\mathrm{Kt}}$ is not well folded in lower $\mathrm{Mg}^{2+}$ concentrations and that neither YbxF nor glycine bind efficiently to the RNA under these conditions. gave $R_{\mathrm{g}}$ values in good agreement with those previously reported both in the absence and presence of saturating glycine (hereafter "free" and "bound," respectively) (Fig. 3A; Lipfert et al. 2007). The Kratky plot of free VcI-II presents a rise at low $q$, followed by a plateau at higher $q$, consistent with a partially folded state (Fig. 3B). The corresponding $P(\mathrm{r})$ plot is broad, with a maximum intramolecular distance, $D_{\max }$ (from the intercept with the abscissa) of $\sim 160 \AA$ (Fig. 3C). Glycine binding to $V c$ I-II induced a compaction $\left(\Delta R_{\mathrm{g}}\right)$ of $\sim 10 \AA$. The Kratky plot of bound $V c$ I-II exhibits a peak at $\sim 0.05 \AA^{-1}$ followed by a falloff at higher $q$, indicative of a better folded RNA (Fig. 3B). The $P(\mathrm{r})$ plot becomes nearly bellshaped, with $D_{\max } \sim 140 \AA$.

The $R_{\mathrm{g}}$ of free $V c \mathrm{I}-\mathrm{II}{ }^{\mathrm{Kt}}$ is $5 \AA$ smaller than that of free $V c \mathrm{I}-\mathrm{II}$. This $\Delta R_{\mathrm{g}}$ resulting from the presence of the K-turn amounts to $50 \%$ of the glycine-binding-induced $\Delta R_{\mathrm{g}}$ observed for $V c \mathrm{I}-$ II (Fig. 3A), suggesting that P0 allows the RNA to pre-fold into a conformation more competent for glycine binding. The presence of a small peak at low $q$ in the Kratky plot (Fig. $3 \mathrm{~B}$ ) also indicates that free $V c \mathrm{I}-\mathrm{II}^{\mathrm{Kt}}$ is better folded than $V c I-I I$. Glycine binding caused additional compaction of $V c \mathrm{I}-\mathrm{II}^{\mathrm{Kt}}$ to an $R_{\mathrm{g}} \sim 35 \AA$. This is $3 \AA$ smaller than the $R_{\mathrm{g}}$ for bound $V c$ I-II. The Kratky and $P(r)$ plots also show that the bound $V c I-I^{\mathrm{Kt}}$ is more compact and better folded than the bound $V c$ I-II (Fig. 3B,C). At a $\mathrm{Mg}^{2+}$ concentration of 10 $\mathrm{mM}$, the free $V c \mathrm{I}-\mathrm{II}^{\mathrm{Kt}} \mathrm{RNA}\left(R_{\mathrm{g}}=37.2 \AA\right)$ is more compact than even the bound $V c$ I-II $\left(R_{\mathrm{g}}=38.1 \AA\right)$.

\section{K-turn dependent compaction of free and bound $\mathrm{VCl}-\mathrm{II}$ and $\mathrm{VCl}-\mathrm{II}^{\mathrm{Kt}}$}

Lipfert et al. $(2007,2010)$ explored the contribution of various cations and glycine to the folding of $\mathrm{VcI}-\mathrm{II}$. Monovalent and divalent cations yielded partially folded states of this RNA construct lacking P0. Additional global compaction was induced by glycine. The glycine-dependent folding required the presence of certain divalent cations, implicating at least one specific metal ion in glycine binding (Lipfert et al. 2010), consistent with subsequent crystallographic structure determination (Huang et al. 2010).
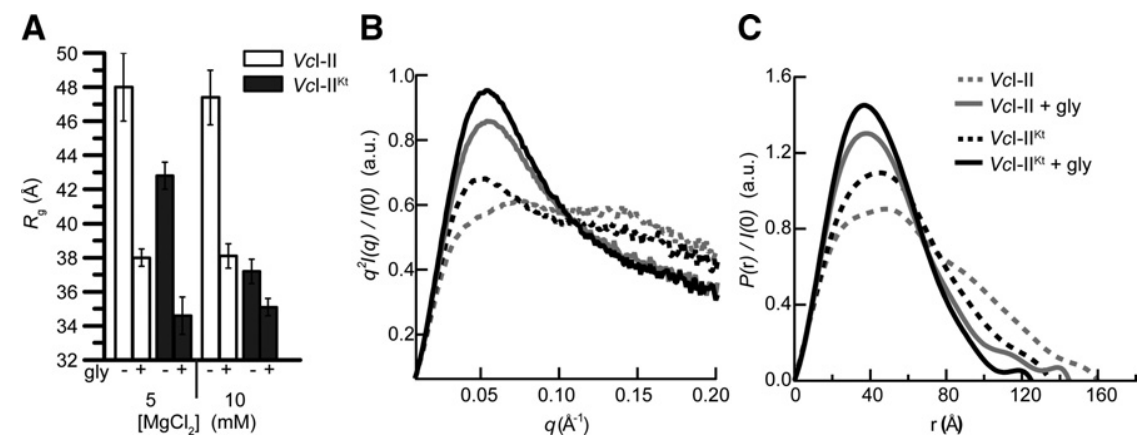

FIGURE 3. SAXS analyses of $V c I-I I$ and $V c I-I I^{\mathrm{Kt}}$. (A) Comparison of $R_{\mathrm{g}}$ in the absence and presence of saturating glycine in $5 \mathrm{mM}$ and $10 \mathrm{mM} \mathrm{Mg}^{2+}$. $(B)$ Kratky and $(C) P(\mathrm{r})$ plots for experiments performed in $5 \mathrm{mM} \mathrm{Mg}{ }^{2+}$ with $V c \mathrm{I}-\mathrm{II}$ and $V c \mathrm{I}-\mathrm{II}^{\mathrm{Kt}}$ in the absence and presence of glycine. 


\section{$\mathrm{Mg}^{2+}$ and $\mathrm{YbxF}$ drive compaction of $B s \mathrm{I}-\mathrm{II}^{\mathrm{Kt}}$ relative to $B$ sI-II}

Although riboswitches appear to be particularly numerous in Gram-positive bacteria (Mandal et al. 2004; Nudler and Mironov 2004), the tandem glycine aptamers of the model organism B. subtilis have not hitherto been subjected to extensive biophysical characterization. We investigated the solution structure of $B s \mathrm{I}-\mathrm{II}$ and $B s \mathrm{I}-\mathrm{II}^{\mathrm{Kt}}$ by SAXS, and compared the effect of the P0 K-turn on this RNA with those we found for the tandem aptamers from $V$. cholerae. The free states of both $B s \mathrm{I}-\mathrm{II}$ and $B s \mathrm{I}-\mathrm{II}^{\mathrm{Kt}}$ have $R_{\mathrm{g}} \sim 46 \AA$ in $5 \mathrm{mM}$ $\mathrm{Mg}^{2+}$ (Fig. 4A). Under these conditions, the K-turn does not have an impact on the global conformation of the tandem aptamers from this species. Addition of $10 \mathrm{mM}$ glycine resulted in compaction of both RNAs, although the $\Delta R_{\mathrm{g}}$ exhibited by $B s \mathrm{I}-\mathrm{II}{ }^{\mathrm{Kt}}$ was twice that of BsI-II. Comparison of the $\Delta R_{\mathrm{g}}$, Kratky, and $P(\mathrm{r})$ plots (Fig. $4 \mathrm{~A}-\mathrm{C}$ ) indicates that bound $B s \mathrm{I}-\mathrm{II}^{\mathrm{Kt}}$ is more compact than BsI-II. At $10 \mathrm{mM} \mathrm{Mg}^{2+}$ concentration, free $B s \mathrm{I}-\mathrm{II}{ }^{\mathrm{Kt}}$ collapsed to $R_{\mathrm{g}} \sim 40 \AA$. This compaction is $\sim 60 \%$ of the total glycine-induced $\Delta R_{\mathrm{g}}$ observed in 5 $\mathrm{mM} \mathrm{Mg}{ }^{2+}$ (Fig. 4A). In contrast, the increased $\mathrm{Mg}^{2+}$ did not significantly alter the global conformations of free or bound $B s \mathrm{I}-\mathrm{II}$ (Fig. 4A). Free BsI-II ${ }^{\mathrm{Kt}}$ in $10 \mathrm{mM} \mathrm{Mg}^{2+}$ is more compact than either free or bound BsI-II (Fig. 4A-D).

We analyzed the cognate interaction between $B$. subtilis $\mathrm{YbxF}$ and BsI-II ${ }^{\mathrm{Kt}}$ and the potential contribution of the protein to the folding of this riboswitch aptamer by SAXS. Because $\mathrm{YbxF}$ binding to BsI-II ${ }^{\mathrm{Kt}}$ increases the mass of the scattering sample, $R_{\mathrm{g}}$ values of the complex are slightly larger than those of the RNA alone. Any observed compaction $\left(\Delta R_{\mathrm{g}}\right)$ of the RNA is thus under-reported in the complex. Also, the final compacted $R_{\mathrm{g}}$ of the complex is slightly larger (by $\sim 1 \AA$ ) than that of the protein-free RNA (Fig. 4A).

Formation of the $\mathrm{YbxF}-\mathrm{Bs} \mathrm{I}-\mathrm{II}^{\mathrm{Kt}}$ complex in $5 \mathrm{mM} \mathrm{Mg}^{2+}$ resulted in a collapse to $R_{\mathrm{g}} \sim 42 \AA$, or $\sim 40 \%$ of the glycine-induced $\Delta R_{\mathrm{g}}$ observed for $B s \mathrm{I}-\mathrm{II}^{\mathrm{Kt}}$. This more compact conformation is evident as a small peak in the Kratky plot (Fig. 4D), the shape of which is reminiscent of that observed for $\mathrm{VcI}-$ $\mathrm{II}^{\mathrm{Kt}}$ (Figs. 3B, 4D) in the absence of protein. Neither increased $\mathrm{Mg}^{2+}$ concentration nor YbxF led to a detectable compaction of the conformation of glycine-bound BsI-II ${ }^{\mathrm{Kt}}$ (Fig. 4A).

We reasoned that since $\mathrm{YbxF}$ compacts free BsI-II ${ }^{\mathrm{Kt}}$ in 5 $\mathrm{mM} \mathrm{Mg}{ }^{2+}$, it might also confer stability to the RNA at lower $\mathrm{Mg}^{2+}$ concentrations. However, because we did not observe any glycine binding to $B s \mathrm{I}-\mathrm{II}^{\mathrm{Kt}}$ by $\mathrm{ITC}$ in $1.5 \mathrm{mM}$ or 2.5 $\mathrm{mM} \mathrm{Mg}^{2+}$ (data not shown), we expected the RNA to be predominantly unfolded in the absence of YbxF. We examined the effect of $\mathrm{YbxF}$ on $B s \mathrm{I}-\mathrm{II}^{\mathrm{Kt}}$ in $1.5 \mathrm{mM} \mathrm{Mg}^{2+}$ by SAXS. Both free and bound BsI-II exhibited $R_{\mathrm{g}}>44 \AA$ in $1.5 \mathrm{mM}$ $\mathrm{Mg}^{2+}$. This suggests that the RNA requires additional $\mathrm{Mg}^{2+}$ for both folding and binding (Fig. 4A). The addition of the K-turn was insufficient to compact the RNA under these conditions. Likewise, YbxF binding did not compact the RNA $\left(R_{\mathrm{g}} \sim 46 \AA\right)$. While neither the K-turn nor YbxF in-

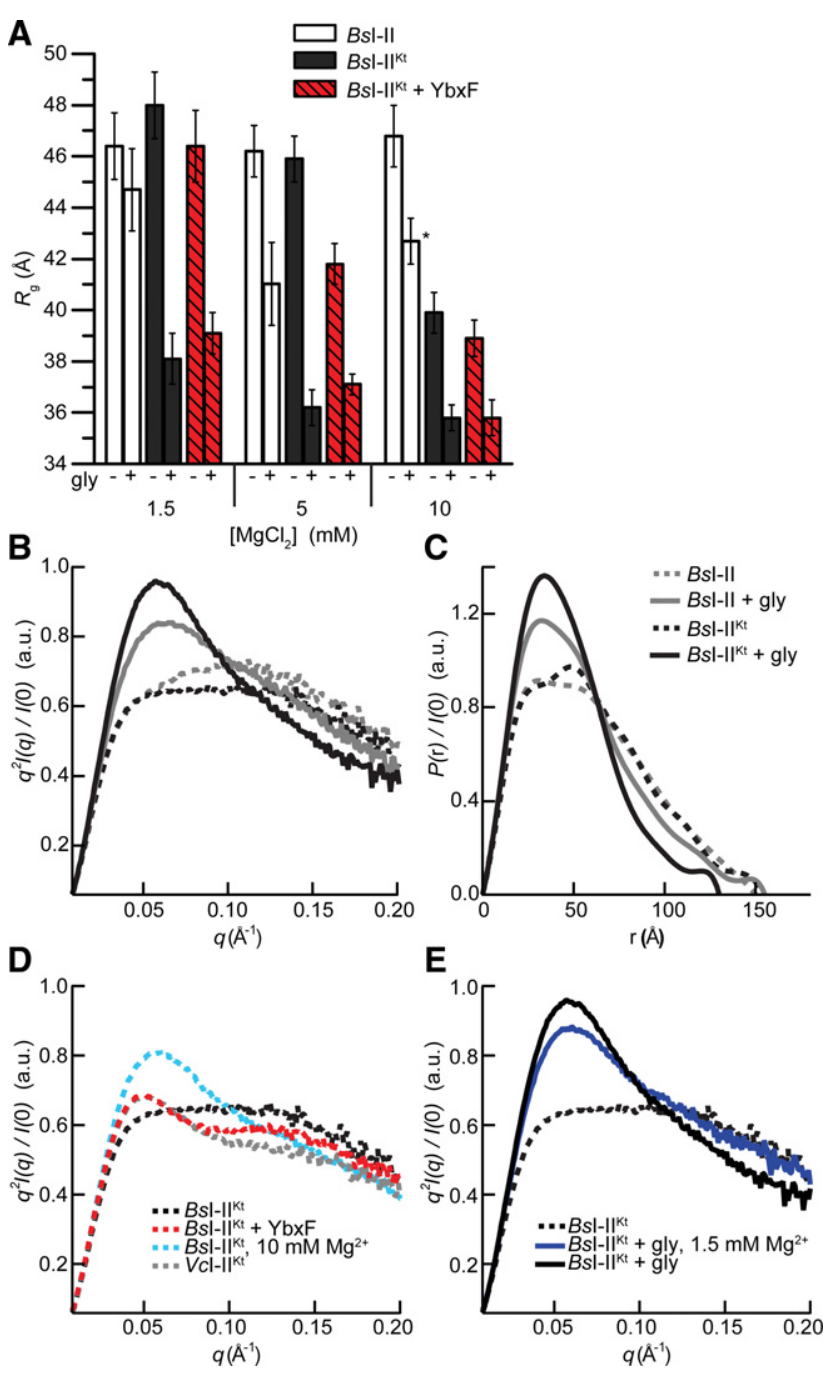

FIGURE 4. SAXS analyses of B. subtilis tandem glycine aptamers. (A) $R_{\mathrm{g}}$ in the absence and presence of saturating glycine in $1.5 \mathrm{mM}, 5$ $\mathrm{mM}$, and $10 \mathrm{mM} \mathrm{Mg}^{2+}$ for BsI-II, BsI-II ${ }^{\mathrm{kt}}$, and BsI-II ${ }^{\mathrm{Kt}}+\mathrm{YbxF}$. Sample marked with asterisk exhibited partial oligomerization (Materials and Methods). (B) Kratky and $(C) P(\mathrm{r})$ plots for experiments performed in $5 \mathrm{mM} \mathrm{Mg}^{2+}$ with $B s \mathrm{I}-\mathrm{II}$ and $B s \mathrm{I}-\mathrm{II}^{\mathrm{Kt}}$ in the absence and presence of glycine. $(D)$ Kratky plots (in $5 \mathrm{mM} \mathrm{Mg}^{2+}$, except where noted) demonstrating the effect of $\mathrm{Mg}^{2+}$ and $\mathrm{YbxF}$ on the structure of BsI$\mathrm{II}^{\mathrm{Kt}}$ in the absence of glycine. $V c \mathrm{I}-\mathrm{II}{ }^{\mathrm{Kt}}$ plot is reproduced from Figure 3D for additional comparison. (E) Kratky plots demonstrating the effect of glycine in $1.5 \mathrm{mM}$ and $5 \mathrm{mM} \mathrm{Mg}^{2+}$.

duced conformational changes to the RNA in $1.5 \mathrm{mM} \mathrm{Mg}^{2+}$, addition of glycine did result in compaction of $B s \mathrm{I}-\mathrm{II}^{\mathrm{Kt}}$ (Fig. 4A). This was surprising given that no heat was evolved in the glycine-binding ITC experiment under these conditions (above). Bound $B s \mathrm{I}-\mathrm{II}^{\mathrm{Kt}}$ has $R_{\mathrm{g}} \sim 38 \AA, \sim 2 \AA$ larger than that observed in 5 or $10 \mathrm{mM} \mathrm{Mg}^{2+}$, suggesting that this RNA is not completely folded. The shape of the Kratky curve also indicates incomplete folding in $1.5 \mathrm{mM} \mathrm{Mg}^{2+}$ as compared with the conformation in $5 \mathrm{mM} \mathrm{Mg}^{2+}$ (Fig. 4E). Regardless, the glycine-induced conformational compaction of $B s \mathrm{I}-\mathrm{II}^{\mathrm{Kt}}$ in $1.5 \mathrm{mM} \mathrm{Mg}^{2+}$ is K-turn dependent (Fig. $4 \mathrm{~A}$ ). 


\section{P0 results in improved ligand binding and modest compaction of glycine-free $\mathrm{FnI}-\mathrm{II}^{\mathrm{Kt}}$}

The unusually compact $F$. nucleatum tandem glycine riboswitch has been the subject of multiple biochemical and structural studies (Kwon and Strobel 2008; Butler et al. 2011; Erion and Strobel 2011; Kladwang et al. 2012; Sherman et al. 2012). Indeed, the only available crystal structure of a tandem glycine riboswitch is for the RNA from this organism (Butler et al. 2011). Since the RNAs used in these crystallographic studies lacked the P0 K-turn, and in light of the significant energetic and structural contribution of the K-turn to folding of and ligand binding by the tandem glycine riboswitch aptamers from $V$. cholerae and B. subtilis, we investigated the effect of including $\mathrm{P} 0$ in the F. nucleatum tandem glycine riboswitch.

As in the cases of the VcI-II and BsI-II described above, ITC experiments in $5 \mathrm{mM} \mathrm{Mg}^{2+}$ did not yield an interpretable binding isotherm for the $F$. nucleatum tandem aptamer construct lacking P0 (Fig. 5). However, heat was evolved for each injection of glycine into FnI-II. The signal was weak and the approach to equilibrium notably slower than those of our other ITC experiments. As the experiment progressed, 10 min between injections became insufficient for re-equilibration of the sample (Fig. 5, top left inset). In contrast, FnI-II ${ }^{\mathrm{Kt}}$ yielded a reproducible binding isotherm at $5 \mathrm{mM} \mathrm{Mg}^{2+}$, and the reaction appeared to attain equilibrium within a few minutes of each injection of glycine (Fig. 5, top right). For $F n \mathrm{I}-\mathrm{II}^{\mathrm{Kt}}$, the binding isotherm is sigmoidal (Fig. 5, bottom right), unlike the isotherms for $\mathrm{VcI}-\mathrm{II}{ }^{\mathrm{Kt}}$ or $B s \mathrm{I}-\mathrm{II}^{\mathrm{Kt}}$ (Fig. $2 \mathrm{~B}, \mathrm{C}$, respectively). The endothermic reaction is entropically driven, with $K_{\mathrm{d}}=6.5 \pm 1 . \mu \mathrm{M}$ and $n=1.46 \pm 0.08$ (Table 2). Because $\mathrm{YbxF}$ binds $F n \mathrm{I}-\mathrm{II}^{\mathrm{Kt}}$ (Fig. 1), we examined its ability to modulate glycine binding by this RNA. Titration

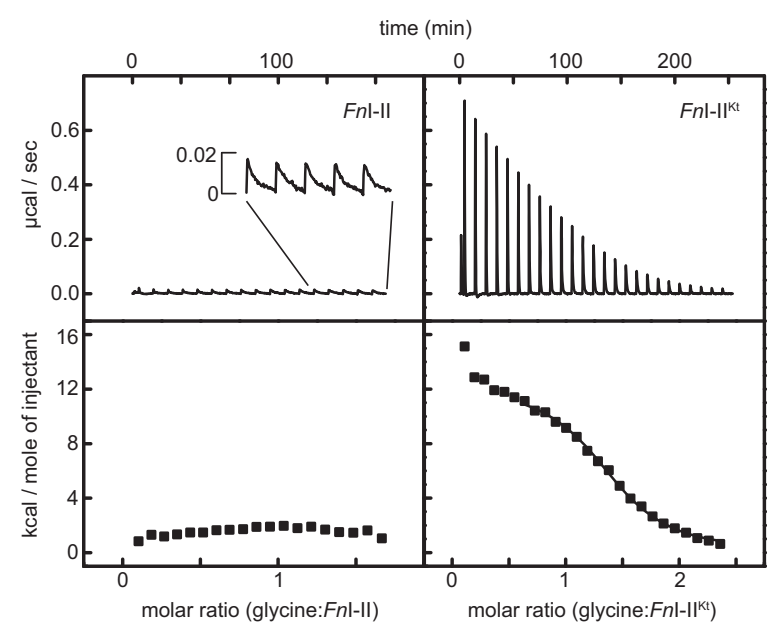

FIGURE 5. ITC analyses of FnI-II and FnI-II ${ }^{\mathrm{Kt}}$. (Left) Titration of glycine into FnI-II. A small heat signal is observed upon injection of glycine (inset) and is very slow to re-equilibrate (>10 min). (Right) Glycine binding by $F n I-I^{\mathrm{Kt}}$ results in a binding isotherm.
TABLE 2. Thermodynamic parameters for $F$. nucleatum tandem aptamers

\begin{tabular}{lccc}
\hline & \multicolumn{1}{c}{$F n \mathrm{l}-\mathrm{Il}$} & $F n \mathrm{l}-\mathrm{II}^{\mathrm{Kt}}$ & $F n \mathrm{l}-\mathrm{II}^{\mathrm{Kt}}+\mathrm{YbxF}$ \\
\hline$n$ & Weak signal, no & $1.46 \pm 0.08$ & $1.29 \pm 0.07$ \\
$K_{\mathrm{d}}(\mu \mathrm{M})$ & binding isotherm & $6.5 \pm 1.5$ & $4.1 \pm 0.1$ \\
$\Delta H(\mathrm{kcal} / \mathrm{mol})$ & & $9.8 \pm 2.6$ & $11.6 \pm 0.2$ \\
$T \Delta S(\mathrm{kcal} / \mathrm{mol})$ & & $16.7 \pm 2.7$ & $18.9 \pm 0.2$ \\
\hline
\end{tabular}

of glycine into $F n \mathrm{I}-\mathrm{II}{ }^{\mathrm{Kt}}$ in the presence of 1.5-molar excess of $\mathrm{YbxF}$ shows that, as in the case of $B s \mathrm{I}-\mathrm{II}{ }^{\mathrm{Kt}}, \mathrm{YbxF}$ slightly increased the glycine-binding affinity of $F n I-I^{\mathrm{Kt}}\left(K_{\mathrm{d}}=4.0\right.$ $\pm 0.01 \mu \mathrm{M})$.

To evaluate whether the structural compaction induced by the P0 K-turn in $V c I-I^{\mathrm{Kt}}$ and $B s \mathrm{I}-\mathrm{II}^{\mathrm{Kt}}$ is a general feature of this class of riboswitches, we examined the F. nucleatum tandem glycine riboswitch by SAXS. In $5 \mathrm{mM} \mathrm{Mg}^{2+}$, the $R_{\mathrm{g}}$ of free $F n I-I I^{\mathrm{Kt}}$ was only $1 \AA$ smaller than that of FnI-II (Fig. 6A). The Kratky and $P(\mathrm{r})$ plots of these two constructs are also very similar (Fig. 6B,C), indicating only a very modest relative compaction of $F n I-I I^{\mathrm{Kt}}$. We next examined whether $\mathrm{YbxF}$ and $\mathrm{Mg}^{2+}$ induce folding of $F n \mathrm{I}-\mathrm{II}^{\mathrm{Kt}}$. In 5 $\mathrm{mM} \mathrm{Mg}^{2+}$, the YbxF-FnI-II ${ }^{\mathrm{Kt}}$ complex was slightly more compact than the free RNA $\left(\Delta R_{\mathrm{g}}=1.8 \AA\right)$. Increasing $\mathrm{Mg}^{2+}$ concentration to $10 \mathrm{mM}$ (in the absence of $\mathrm{YbxF}$ ) folded $F n \mathrm{I}-\mathrm{II}^{\mathrm{Kt}}$ to a larger extent $\left(\Delta R_{\mathrm{g}}=4.7 \AA\right)$ (Fig. $\left.6 \mathrm{~A}\right)$, similarly to what was observed for free $V c \mathrm{I}-\mathrm{II}{ }^{\mathrm{Kt}}$ and $B s \mathrm{I}-\mathrm{II}{ }^{\mathrm{Kt}}$ (Figs. 3, 4). Addition of $\mathrm{YbxF}$ to $F n \mathrm{I}-\mathrm{II}^{\mathrm{Kt}}$ in $10 \mathrm{mM} \mathrm{Mg}^{2+}$ did not result in additional compaction of the $R_{\mathrm{g}}$ (Fig. $6 \mathrm{~A}$ ). It is important to note that the $\Delta R_{\mathrm{g}}$ is under-reported for the $\mathrm{YbxF}-$ $F n \mathrm{I}-\mathrm{II}^{\mathrm{Kt}}$ complex in both $5 \mathrm{mM}$ and $10 \mathrm{mM}$. The binding of YbxF to the relatively small $F n I-I I^{\mathrm{Kt}}$ RNA increases the mass of the scattering sample by $\sim 16 \%$, and thus increases the $R_{\mathrm{g}}$. Any compaction of the glycine-free RNA is offset by the increase in $R_{\mathrm{g}}$ of the complex. This is most readily observed as a larger $R_{\mathrm{g}}(>1.5 \AA)$ for the glycine-bound conformation of the YbxF-FnI-II ${ }^{\mathrm{Kt}}$ complex relative the $R_{\mathrm{g}}$ of the RNA alone (Fig. 6A).

In the Kratky plot (Fig. 6D), YbxF binding in $5 \mathrm{mM} \mathrm{Mg}^{2+}$ resulted in the emergence of a slight peak just above 0.05 $\AA^{-1}$, consistent with the slight reduction in $R_{\mathrm{g}}$ (Fig. $6 \mathrm{~A}$ ). Even absent $\mathrm{YbxF}$, this peak became more pronounced in $10 \mathrm{mM} \mathrm{Mg}^{2+}$ as the RNA compacted further $\left(\Delta R_{\mathrm{g}}=4.7 \AA\right)$ (Fig. 6A,D). Addition of glycine to FnI-II and FnI-II ${ }^{\mathrm{Kt}}$ resulted in their maximal observed folding. Both constructs exhibited nearly identical $R_{\mathrm{g}}$ 's $(\sim 27.7 \AA)$, Kratky, and $P(\mathrm{r})$ plots (Fig. 6A-C). Thus, at the resolution of the SAXS experiment, the presence of the P0 K-turn does not induce additional folding of the glycine-bound tandem aptamers of the $F$. nucleatum riboswitch. This is in marked contrast to the stabilization by the K-turn of the overall bound conformations of $V$. cholerae and B. subtilis tandem glycine riboswitches (Figs. 3, 4). 

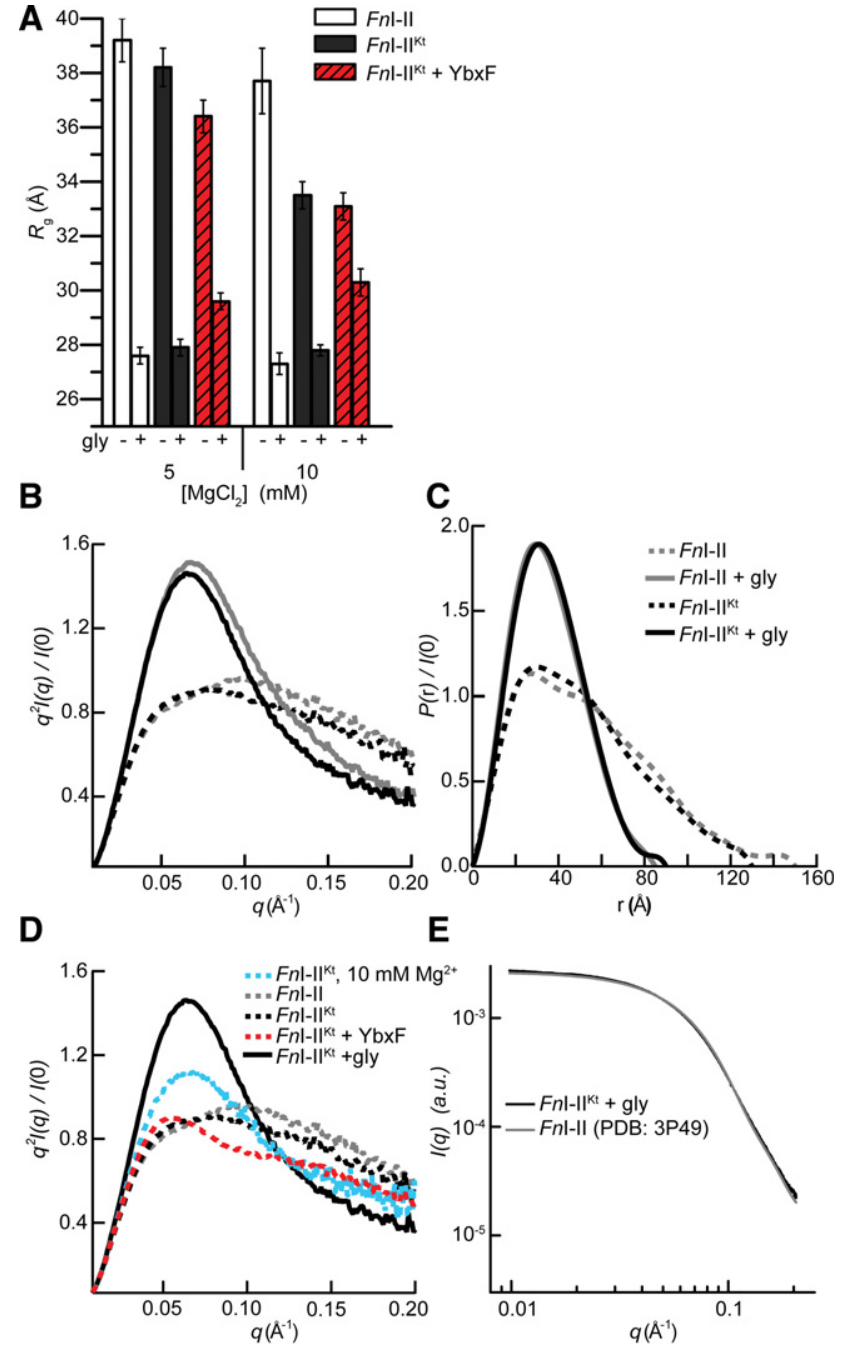

E

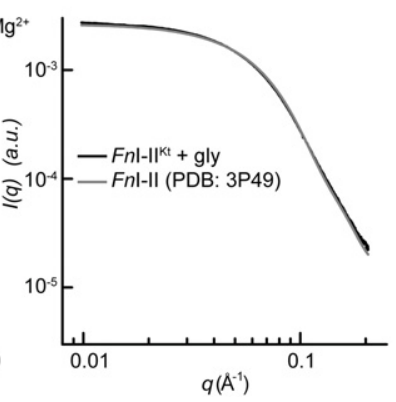

FIGURE 6. SAXS analyses of $F n \mathrm{I}-\mathrm{II}, F n \mathrm{I}-\mathrm{II}^{\mathrm{Kt}}$, and $F n \mathrm{I}-\mathrm{II}^{\mathrm{Kt}}+\mathrm{YbxF} .(A)$ $R_{\mathrm{g}}$ in the absence and presence of saturating glycine in $5 \mathrm{mM}$ and 10 $\mathrm{mM} \mathrm{Mg}^{2+}$. (B) Kratky and (C) $P(\mathrm{r})$ plots from data collected at $5 \mathrm{mM}$ $\mathrm{Mg}^{2+}$ demonstrate glycine-binding-induced compaction. (D) Kratky plots comparing the effect of $\mathrm{Mg}^{2+}, \mathrm{YbxF}$, and glycine on folding of $F n I-I^{\mathrm{Kt}}$ (in $5 \mathrm{mM} \mathrm{Mg}^{2+}$, except where noted). (E) Comparison of the experimental X-ray scattering profile for $F n I-I^{\mathrm{Kt}}$ with the scattering profile calculated (Materials and Methods) from the crystal structure (Butler et al. 2011) of FnI-II.

\section{DISCUSSION}

On the basis of in-line probing and hydroxyl radical footprinting data, Sherman et al. (2012) concluded that interaptamer interactions and glycine binding act synergistically to fold the glycine riboswitch. Moreover, they found that their data could not distinguish between the glycine-bound states of I-II and I-II ${ }^{\mathrm{Kt}}$ tandem aptamer constructs. Since chemical probing and footprinting experiments report on local reactivity of the nucleic acid, extrapolations from the results of such experiments to the global conformation of an RNA are inferences that need to be tested. SAXS experiments allow rapid comparison of the overall conformations of RNAs in various solution conditions. Our SAXS data indicate that, under physiological $\mathrm{Mg}^{2+}$ concentrations and in the absence of glycine, the K-turn does induce partial folding of the tandem aptamers of constructs from all three bacterial species tested. However, we find that $V c \mathrm{I}-\mathrm{II}{ }^{\mathrm{Kt}}$ and $B s \mathrm{I}-\mathrm{II}{ }^{\mathrm{Kt}}$ exhibit a glycinebound global conformation that is more compact than those of their respective I-II constructs bound to glycine. Thus, under our experimental conditions, the P0 K-turns confer on these two riboswitches more stability, even in their glycinebound states.

The global thermodynamic response of tandem glycine aptamer constructs is overall consistent with our SAXS results. For all three species tested, only constructs containing the K-turn show evidence of glycine binding by ITC at 5 $\mathrm{mM} \mathrm{Mg}{ }^{2+}$. At this $\mathrm{Mg}^{2+}$ concentration, constructs lacking the K-turn produced no appreciable heat when titrated with glycine. Nonetheless, SAXS experiments demonstrated glycine-induced global compaction for each I-II construct. Given the lack of heat evolution detectable by ITC, this glycine-dependent conformational change of constructs lacking P0 is likely entropically driven. Numerical fits to our ITC data are consistent with different glycine:RNA stoichiometries for the three $\mathrm{I}-\mathrm{II}^{\mathrm{Kt}}$ constructs (Tables 1, 2). Even though the length and composition of various peripheral helical elements vary between the two aptamers of each construct, the sequences of their glycine-binding pockets are highly conserved. Thus, it was expected (Mandal et al. 2004) that two glycine molecules would bind to each dual aptamer RNA. Our ITC experiments reveal that the molar ratio (glycine:RNA) required to saturate the RNAs is $<2$ (Figs. 2, 5). Only $F n I-I^{\mathrm{Kt}}$ exhibited a binding stoichiometry $>1(n \sim$ 1.5) (Table 2). For $V c I-I I^{\mathrm{Kt}}$ the binding stoichiometry is unity (Table 1), while that observed for BsI-II ${ }^{\mathrm{Kt}}$ is subunity (Table 1). Intriguingly, the mean Hill coefficients previously determined by Sherman et al. (2012) from fits to their in-line probing data were subunity for all three $\mathrm{I}-\mathrm{II}^{\mathrm{Kt}}$ constructs, which led those investigators to suggest that no glycine-binding cooperativity exists between the aptamers. In addition, structure determination of a tandem glycine aptamer construct (Butler et al. 2011) revealed only weak electron density that could be attributed to glycine. Those investigators reported that averaging of binding pocket electron density between the two aptamers and across two data sets resulted in improved glycine electron density for aptamer 1 . Taken together, these results hint that glycine may not bind efficiently to both aptamers in some tandem glycine riboswitches.

Previous reports suggested that the K-turns of bacterial riboswitches containing this motif might be bound in vivo by proteins. Those studies (Blouin and Lafontaine 2007; Heppell and Lafontaine 2008) utilized the archaeal protein L7Ae. We recently found crystallographically that the B. subtilis protein $\mathrm{YbxF}$ is structurally homologous to L7Ae and that it binds to K-turns (Baird et al. 2012). Because the P0 K-turn is necessary for folding and glycine binding by the B. subtilis glycine riboswitch, we examined the effect of the B. subtilis $\mathrm{YbxF}$ 
on $B s \mathrm{I}-\mathrm{II}{ }^{\mathrm{Kt}}$, finding that the protein provides a modest but reproducible increase in glycine-binding affinity of the RNA. To our knowledge, this is the first demonstration that formation of a cognate RNP enhances ligand binding by a riboswitch. Our SAXS experiments show that YbxF binding resulted in more compact global conformation of BsI-II ${ }^{\mathrm{Kt}}$ (Fig. 4). We speculate that YbxF binding of the K-turn of this RNA partially orients the two aptamers relative to each other. This prefolding facilitates subsequent glycine binding. Notably, the P0 K-turn alone is insufficient to pre-fold BsI-II ${ }^{\mathrm{Kt}}$; the Kturn binding protein $\mathrm{YbxF}$ is required to achieve this under physiologic $\mathrm{Mg}^{2+}$ concentrations. Therefore, the B. subtilis glycine riboswitch may function as an RNP. We have been unable to detect a YbxF homolog in the $V$. cholerae genome using BLAST (Altschul et al. 1997). This would be consistent with our SAXS demonstration that $V c \mathrm{I}-\mathrm{II}^{\mathrm{Kt}}$ does not require a protein to achieve folding (Figs. 3B, 4D).

Our SAXS experiments show that the K-turn supports a partially compacted glycine-free conformation of $F n I-I^{\mathrm{Kt}}$ and that this RNA is stabilized further by $\mathrm{YbxF}$ or increased $\mathrm{Mg}^{2+}$ concentrations. In contrast to the behavior of the RNAs from B. subtilis and V. cholerae, the K-turn does not affect the overall glycine-bound conformation of the F. nucleatum tandem aptamer constructs. To confirm this observation, we calculated the solution X-ray scattering profile expected from the crystal structure of FnI-II (Butler et al. 2011) using CRYSOL (Svergun et al. 1995). This profile agrees very closely with the experimental scattering profile of glycine-bound FnI$\mathrm{II}^{\mathrm{Kt}}$ over the entire $q$-range (Fig. $6 \mathrm{E}$ ). With the caveat that SAXS cannot resolve structural detail, it thus appears that the unusually compact glycine riboswitch from $F$. nucleatum can form its full complement of glycine-binding-induced quaternary interactions in the absence of P0. Most glycine riboswitches resemble the RNAs from $V$. cholerae and $B$. subtilis and contain longer or additional helices in each of their two aptamers. Additional quaternary interactions between these elements may be required for these RNAs to fold fully, and the $\mathrm{P} 0 \mathrm{~K}$-turn, as well as possibly a K-turn binding protein likely facilitate those. The variable requirement for P0 among glycine riboswitches is consistent with the species-to-species variation observed for riboswitches of other families (Baird and Ferré-D’Amaré 2010; Baird et al. 2010).

Structured RNAs exhibit an interesting dichotomy in that point mutations may lead to complete loss of function (Pitt and Ferré-D’Amaré 2010), yet omission of entire structural motifs may still allow limited folding and function. The previously reported ability of tandem glycine aptamers lacking the P0 K-turn to fold and bind glycine in vitro (Mandal et al. 2004; Lipfert et al. 2007; Kwon and Strobel 2008; Huang et al. 2010; Lipfert et al. 2010; Butler et al. 2011; Erion and Strobel 2011) is reminiscent of the results of truncation of the hammerhead and hairpin ribozymes. In studies of the former, efforts to generate a kinetically well-behaved minimal ribozyme yielded an RNA construct amenable to biochemical and structural characterization (for review, see
Blount and Uhlenbeck 2005). However, later discovery of an important peripheral interaction (De la Peña et al. 2003; Khvorova et al. 2003) resulted in an RNA construct with faster cleavage rates (Canny et al. 2004) and a substantially altered active site conformation (Martick and Scott 2006; for review, see Ferré-D'Amaré and Scott 2010). Similarly, early studies of the hairpin ribozyme identified a minimal catalytic construct, which required only two RNA stems with appropriate internal loop sequences (Hampel and Tritz 1989; Hampel et al. 1990). Later, a hairpin ribozyme comprising the natural four-way junction was found to exhibit an increased cleavage rate and a significantly reduced requirement for divalent metal ions relative to the minimal construct (Murchie et al. 1998; for review, see Ferré-D'Amaré 2004). Here, we have shown through ITC and SAXS experiments that the P0 element recently discovered by Kladwang et al. (2012) and Sherman et al. (2012) in tandem glycine riboswitches increases the ligand binding affinity and modulates the overall quaternary arrangement of the aptamers, resulting in a considerably more compact RNA that folds under physiologic conditions.

\section{MATERIALS AND METHODS}

\section{RNA and protein constructs}

Six RNAs were used in this study. Individual plasmids containing the dual aptamer glycine riboswitches from the $V$. cholerae VC1422, B. subtilis gcvT, and F. nucleatum FN0328 genes were generated by PCR of overlapping synthetic oligomers ( $V$. cholerae and $F$. nucleatum constructs), or PCR from genomic DNA (B. subtilis construct) followed by TOPO TA cloning (Invitrogen; Bs and Fn constructs), or ligation into pUC19 vector ( $V c$ construct). The sequences of resulting plasmids were confirmed by Sanger sequencing. DNA templates for transcription were PCR amplified from the individual plasmids. Unique forward primers were used to generate constructs with or without the K-turn sequence upstream of the first aptamer. Sequences of the $5^{\prime}$ and $3^{\prime}$ termini the constructs are as follows: $V c I-I I 5^{\prime}$-GGGTTGAAGACTGCAG ... GGACAGAG-3'; $V c I-$ II $^{\mathrm{Kt}} 5^{\prime}$-GGTTCCGTTGAAGACTG CAG ... GGACAGAG-3'; BsI-II $5^{\prime}$-GGAGCAAGGG ... GG ACAGAG-3'; BsI-II ${ }^{\mathrm{Kt}} 5^{\prime}$-GGCGAATG ACAGCAAGGG ... GGACAGAG-3'; FnI-II $5^{\prime}$-GGATATGAG ... GGACGGAG-3'; FnI-II ${ }^{\mathrm{Kt}}$ 5'-GGTCGGATGAAGATATGAG ... GGACG GAG-3'. All RNA constructs were transcribed from PCR products essentially as described (Xiao et al. 2008). RNAs were purified using denaturing PAGE, electroeluted (Elutrap, GE), and concentrated and exchanged with $1 \mathrm{M} \mathrm{KCl}$ once and with water three times using centrifugal ultrafiltration (Amicon Ultra, $10 \mathrm{~K}$ MWCO, Millipore). RNAs were stored at $4^{\circ} \mathrm{C}$ prior to use. L7Ae and $\mathrm{YbxF}$ were expressed and purified as described (Hamma and Ferré-D’Amaré 2004; Baird et al. 2012).

\section{Isothermal titration calorimetry}

RNA $(\sim 200 \mu \mathrm{M})$ was heated to $85^{\circ} \mathrm{C}$ in $20 \mathrm{mM}$ HEPES- $\mathrm{KOH}(\mathrm{pH}$ 7.5 ) and $100 \mathrm{mM} \mathrm{KCl}$ for $2 \mathrm{~min}$, followed by cooling to room temperature for $5 \mathrm{~min}$. Concentrated $\mathrm{MgCl}_{2}$ was added $(\sim 1 \mu \mathrm{L})$ to a final 
concentration of $5 \mathrm{mM}$, followed by incubation at $37^{\circ} \mathrm{C}$ for $10 \mathrm{~min}$. RNA was equilibrated in RNA folding buffer (20 mM HEPES- $\mathrm{KOH}$ at $\mathrm{pH} 7.5,100 \mathrm{mM} \mathrm{KCl}, 5 \mathrm{mM} \mathrm{MgCl}$ ) by exchanging three times using centrifugal ultrafiltration (Amicon Ultra, Millipore). For the relevant experiments, 1.5 molar equivalents of $\mathrm{YbxF}$ were added prior to buffer exchange. For YbxF containing samples, the buffer was supplemented with $1 \mathrm{mM}$ TCEP. Samples were diluted to a final concentration of 50-150 $\mu \mathrm{M}$ RNA in RNA folding buffer prior to placement in the ITC cell (Microcal iTC ${ }_{200}$, GE). The titration syringe contained $10-40 \times$ concentration (relative to that of the RNA in the calorimeter cell) of glycine in RNA folding buffer. All experiments were performed at $20^{\circ} \mathrm{C}$. ITC experiments were analyzed using the singlesite fit in the $\mathrm{iTC}_{200}$ software. Consistently, data below a molar ratio 0.5:1 (glycine:RNA) could not be analyzed. Inclusion of data points below this molar ratio yielded poor fits to the data and increased residuals to the fit. Attempts to fit the data to two sites resulted in larger residuals and overall poorer fit to the data. ITC experiments of $V c$ I-II previously reported by Huang et al. (2010) were fitted assuming a single site after omission of initial data points. In order to facilitate comparison with the literature, we adopted this convention. ITC experiments were performed in triplicate for $\mathrm{I}-\mathrm{II}^{\mathrm{Kt}}$ constructs, duplicate for I-II ${ }^{\mathrm{Kt}}-\mathrm{YbxF}$ complexes, and as single experiments for I-II constructs. None of the experiments yielded a binding ratio of 2:1 (glycine:RNA) at saturation. Even when the final molar ratio (glycine:RNA) in solution was $>8$, no additional binding was observed. Only the fit to the FnI-II ${ }^{\mathrm{Kt}}$ data indicated $n>1$. Samples for RNA folding experiments monitored by ITC were prepared as described above, except that RNA concentration was $50 \mu \mathrm{M}$ and $\mathrm{Mg}^{2+}$ was not added prior to ITC. The titration syringe was filled with 100

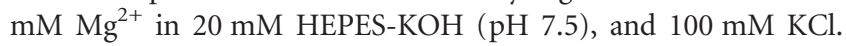
Uncertainties reported in Tables 1 and 2 are the standard errors of the mean of fits to replicate experiments.

\section{Small-angle X-ray scattering}

Samples for SAXS were annealed and folded as described for ITC experiments. Then, they were subjected to size-exclusion chromatography (Superdex 200, GE) in RNA folding buffer. Each construct exhibited varying fractions of aggregated, dimeric, and monomeric RNA. Integrated peak areas monitored by absorbance at $290 \mathrm{~nm}$ indicate that $70 \%-95 \%$ of total RNA loaded was monomeric. Fractions containing the monomer were pooled and concentrated (Amicon Ultra, Millipore). Concentrated samples were then split for buffer exchange by ultrafiltration; samples were exchanged at least three times into buffers containing final experimental $\mathrm{MgCl}_{2}$ and glycine concentrations $\left(1.5 \mathrm{mM} \mathrm{Mg}{ }^{2+}, 10 \mathrm{mM}\right.$ glycine; $5 \mathrm{mM}$

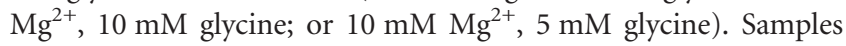
were diluted to a final concentration of $\sim 0.5,1.0$, or $2.0 \mathrm{~g} / \mathrm{L}$ and shipped to the synchrotron facility overnight at $4^{\circ} \mathrm{C}$. SAXS experiments were conducted at the Advanced Photon Source ID-12 BESSRC. Data were collected essentially as described elsewhere (Kulshina et al. 2009). Single experiments at a concentration of $0.5 \mathrm{~g} / \mathrm{L}$ were performed for all samples in $1.5 \mathrm{mM}$ and $5 \mathrm{mM} \mathrm{Mg}^{2}$ + except for BsI-II + glycine, as noted below. B. subtilis and F. nucleatum samples in $10 \mathrm{mM} \mathrm{Mg}{ }^{2+}$ were collected in triplicate as a concentration series at $0.5,1.0$, and $2.0 \mathrm{~g} / \mathrm{L}$, except BsI-II ${ }^{\mathrm{Kt}}$ and $F n \mathrm{I}-\mathrm{II}{ }^{\mathrm{Kt}}$ samples including $\mathrm{YbxF}$ were collected as single experiments. No concentration dependence of $R_{\mathrm{g}}$ was observed for any sample in $10 \mathrm{mM} \mathrm{Mg}^{2+}$, except BsI-II + glycine. For the latter, samples were analyzed by native PAGE after the SAXS experiment and found to contain a small fraction of oligomer that migrated more slowly than the folded, monomeric RNA. Therefore, in an effort to remove oligomers, new samples of $B s I-I I+$ glycine in $10 \mathrm{mM} \mathrm{Mg}^{2+}$ were prepared and purified as described above. SAXS data collected from the new samples still exhibited concentration dependence of $R_{\mathrm{g}}$. The $R_{\mathrm{g}}$ reported in Figure 4 was calculated from the scattering profile of the sample with the lowest concentration, even though slight oligomerization was present. As a precaution, the BsI-II + glycine in $5 \mathrm{mM} \mathrm{Mg}^{2+}$ measurement was performed in triplicate, given the observed concentration dependence in $10 \mathrm{mM} \mathrm{Mg}^{2+}$. However, no concentration dependence was observed in $5 \mathrm{mM} \mathrm{Mg}^{2+}$. Errors in $R_{\mathrm{g}}$ represent the variance between measurements for experiments performed in duplicate or triplicate. For single measurements, the uncertainty reported is taken from the fit to the data in the Guinier plot. SAXS data analysis was performed using Igor (Wavemetrics) and GNOM (Svergun 1992). The scattering profile of $F n I-I I$ was calculated using the atomic coordinates of Butler et al. (2011; PDB ID: 3P49) and the program CRYSOL (Svergun et al. 1995). The U1A protein and its binding site, used to facilitate crystallization (Ferré-D'Amaré 2010), were removed and the crystallographically observed water, counterions, and glycine were stripped prior to the calculation.

\section{Electrophoretic mobility shift assay}

Aliquots of monomeric $V c \mathrm{I}-\mathrm{II}^{\mathrm{Kt}}, B s \mathrm{I}-\mathrm{II}^{\mathrm{Kt}}$, and FnI-II ${ }^{\mathrm{Kt}}(\sim 3 \mu \mathrm{g})$ were taken from the samples purified by size-exclusion chromatography for SAXS experiments. Individual aliquots were mixed with no protein or more than fivefold molar excess (to ensure saturation) of L7Ae or YbxF, and were analyzed on a $8 \%$ polyacrylamide, $0.5 \times$ THE (Baird et al. 2012), $5 \mathrm{mM} \mathrm{MgCl}_{2}$ gel. Buffer mixing, electrophoresis, and RNA visualization were as described (Kulshina et al. 2010).

\section{ACKNOWLEDGMENTS}

We thank K. Deigan, X. Yang, and the staff of ID-12 BESSRC CAT at the Advanced Photon Source, Argonne National Laboratory, for assistance with SAXS data collection, Y.-X. Wang for generously providing beam time, and G. Piszczek for discussions on ITC data analysis. This research was supported by the Intramural Research Program of the NIH, National Heart, Lung, and Blood Institute.

Received September 4, 2012; accepted November 3, 2012.

\section{REFERENCES}

Alatossava T, Jutte H, Kuhn A, Kellenberger E. 1985. Manipulation of intracellular magnesium content in polymyxin B nonapeptide-sensitized Escherichia coli by ionophore A23187. J Bacteriol 162: 413419.

Altschul SF, Madden TL, Schaffer AA, Zhang J, Zhang Z, Miller W, Lipman DJ. 1997. Gapped BLAST and PSI-BLAST: A new generation of protein database search programs. Nucleic Acids Res 25: 3389-3402.

Ames TD, Breaker RR. 2011. Bacterial aptamers that selectively bind glutamine. RNA Biol 8: 82-89.

Baird NJ, Ferré-D’Amaré AR. 2010. Idiosyncratically tuned switching behavior of riboswitch aptamer domains revealed by comparative small-angle X-ray scattering analysis. RNA 16: 598-609. 
Baird NJ, Westhof E, Qin H, Pan T, Sosnick TR. 2005. Structure of a folding intermediate reveals the interplay between core and peripheral elements in RNA folding. J Mol Biol 352: 712-722.

Baird NJ, Kulshina N, Ferré-D'Amaré AR. 2010. Riboswitch function: Flipping the switch or tuning the dimmer? RNA Biol 7: 328-332.

Baird NJ, Zhang J, Hamma T, Ferré-D'Amaré AR. 2012. YbxF and YlxQ are bacterial homologs of L7Ae and bind K-turns but not K-loops. RNA 18: 759-770.

Blouin S, Lafontaine DA. 2007. A loop-loop interaction and a K-turn motif located in the lysine aptamer domain are important for the riboswitch gene regulation control. RNA 13: 1256-1267.

Blount KF, Uhlenbeck OC. 2005. The structure-function dilemma of the hammerhead ribozyme. Annu Rev Biophys Biomol Struct 34: 415-440.

Butler EB, Xiong Y, Wang J, Strobel SA. 2011. Structural basis of cooperative ligand binding by the glycine riboswitch. Chem Biol 18: 293-298.

Canny MD, Jucker FM, Kellogg E, Khvorova A, Jayasena SD, Pardi A. 2004. Fast cleavage kinetics of a natural hammerhead ribozyme. J Am Chem Soc 126: 10848-10849.

De la Peña M, Gago S, Flores R. 2003. Peripheral regions of natural hammerhead ribozymes greatly increase their self-cleavage activity. EMBO J 22: 5561-5570.

Erion TV, Strobel SA. 2011. Identification of a tertiary interaction important for cooperative ligand binding by the glycine riboswitch. RNA 17: 74-84.

Ferré-D'Amaré AR. 2004. The hairpin ribozyme. Biopolymers 73: 71-78.

Ferré-D'Amaré AR. 2010. Use of the spliceosomal protein U1A to facilitate crystallization and structure determination of complex RNAs. Methods 52: 159-167.

Ferré-D’Amaré AR, Scott WG. 2010. Small self-cleaving ribozymes. Cold Spring Harb Perspect Biol 2: a003574. doi: 10.1101/cshperspect. a003574.

Hamma T, Ferré-D’Amaré AR. 2004. Structure of protein L7Ae bound to a K-turn derived from an archaeal box H/ACA sRNA at $1.8 \AA$ resolution. Structure 12: 893-903.

Hampel A, Tritz R. 1989. RNA catalytic properties of the minimum (-) sTRSV sequence. Biochemistry 28: 4929-4933.

Hampel A, Tritz R, Hicks M, Cruz P. 1990. 'Hairpin' catalytic RNA model: Evidence for helices and sequence requirement for substrate RNA. Nucleic Acids Res 18: 299-304.

Heppell B, Lafontaine DA. 2008. Folding of the SAM aptamer is determined by the formation of a K-turn-dependent pseudoknot. Biochemistry 47: 1490-1499.

Huang L, Serganov A, Patel DJ. 2010. Structural insights into ligand recognition by a sensing domain of the cooperative glycine riboswitch. Mol Cell 40: 774-786.

Khvorova A, Lescoute A, Westhof E, Jayasena SD. 2003. Sequence elements outside the hammerhead ribozyme catalytic core enable intracellular activity. Nat Struct Biol 10: 708-712.

Kladwang W, Chou FC, Das R. 2012. Automated RNA structure prediction uncovers a kink-turn linker in double glycine riboswitches. J Am Chem Soc 134: 1404-1407.

Klein DJ, Schmeing TM, Moore PB, Steitz TA. 2001. The kink-turn: A new RNA secondary structure motif. EMBO J 20: 4214-4221.

Kulshina N, Baird NJ, Ferré-D’Amaré AR. 2009. Recognition of the bacterial second messenger cyclic diguanylate by its cognate riboswitch. Nat Struct Mol Biol 16: 1212-1217.
Kulshina N, Edwards TE, Ferré-D’Amaré AR. 2010. Thermodynamic analysis of ligand binding and ligand binding-induced tertiary structure formation by the thiamine pyrophosphate riboswitch. RNA 16: $186-196$.

Kwon M, Strobel SA. 2008. Chemical basis of glycine riboswitch cooperativity. RNA 14: 25-34.

Lipfert J, Das R, Chu VB, Kudaravalli M, Boyd N, Herschlag D, Doniach S. 2007. Structural transitions and thermodynamics of a glycinedependent riboswitch from Vibrio cholerae. J Mol Biol 365: 1393-1406.

Lipfert J, Sim AY, Herschlag D, Doniach S. 2010. Dissecting electrostatic screening, specific ion binding, and ligand binding in an energetic model for glycine riboswitch folding. RNA 16: 708-719.

Mandal M, Lee M, Barrick JE, Weinberg Z, Emilsson GM, Ruzzo WL, Breaker RR. 2004. A glycine-dependent riboswitch that uses cooperative binding to control gene expression. Science 306: 275-279.

Martick M, Scott WG. 2006. Tertiary contacts distant from the active site prime a ribozyme for catalysis. Cell 126: 309-320.

Monod J, Wyman J, Changeux JP. 1965. On the nature of allosteric transitions: A plausible model. J Mol Biol 12: 88-118.

Murchie AI, Thomson JB, Walter F, Lilley DM. 1998. Folding of the hairpin ribozyme in its natural conformation achieves close physical proximity of the loops. Mol Cell 1: 873-881.

Nudler E, Mironov AS. 2004. The riboswitch control of bacterial metabolism. Trends Biochem Sci 29: 11-17.

Pitt JN, Ferré-D’Amaré AR. 2010. Rapid construction of empirical RNA fitness landscapes. Science 330: 376-379.

Romani A, Scarpa A. 1992. Regulation of cell magnesium. Arch Biochem Biophys 298: 1-12.

Schroeder KT, McPhee SA, Ouellet J, Lilley DMJ. 2010. A structural database for k-turn motifs in RNA. RNA 16: 1463-1468.

Schroeder KT, Daldrop P, Lilley DMJ. 2011. RNA tertiary interactions in a riboswitch stabilize the structure of a kink turn. Structure 19: 1233-1240.

Sherman EM, Esquiaqui J, Elsayed G, Ye JD. 2012. An energetically beneficial leader-linker interaction abolishes ligand-binding cooperativity in glycine riboswitches. RNA 18: 496-507.

Sudarsan N, Hammond MC, Block KF, Welz R, Barrick JE, Roth A, Breaker RR. 2006. Tandem riboswitch architectures exhibit complex gene control functions. Science 314: 300-304.

Sudarsan N, Lee ER, Weinberg Z, Moy RH, Kim JN, Link KH, Breaker RR. 2008. Riboswitches in eubacteria sense the second messenger cyclic di-GMP. Science 321: 411-413.

Svergun DI. 1992. Determination of the regularization parameter in indirect-transform methods using perceptual criteria. J Appl Crystallogr 25: 495-503.

Svergun DI, Barberato C, Koch MHJ. 1995. CRYSOL - a program to evaluate X-ray solution scattering of biological macromolecules from atomic coordinates. J Appl Crystallogr 28: 768-773.

Welz R, Breaker R. 2007. Ligand binding and gene control characteristics of tandem riboswitches in Bacillus anthracis. RNA 13: 573-582.

Woodson SA. 2005. Metal ions and RNA folding: A highly charged topic with a dynamic future. Curr Opin Chem Biol 9: 104-109.

Xiao H, Edwards TE, Ferré-D’Amaré AR. 2008. Structural basis for specific, high-affinity tetracycline binding by an in vitro evolved aptamer and artificial riboswitch. Chem Biol 15: 1125-1137. 

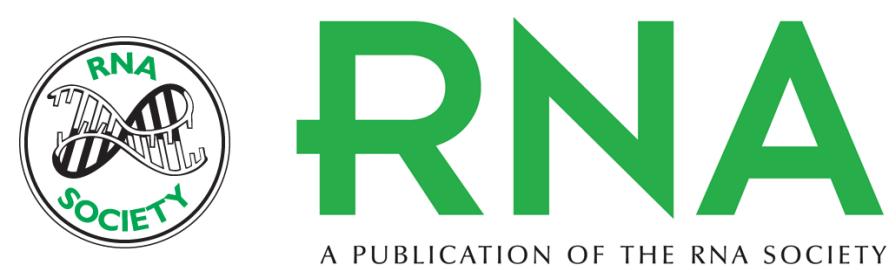

\title{
Modulation of quaternary structure and enhancement of ligand binding by the K-turn of tandem glycine riboswitches
}

\author{
Nathan J. Baird and Adrian R. Ferré-D'Amaré
}

RNA 2013 19: 167-176 originally published online December 17, 2012

Access the most recent version at doi:10.1261/rna.036269.112

\section{References This article cites 46 articles, 18 of which can be accessed free at: http://rnajournal.cshlp.org/content/19/2/167.full.html\#ref-list-1}

\section{License}
Email Alerting Receive free email alerts when new articles cite this article - sign up in the box at the Service top right corner of the article or click here.

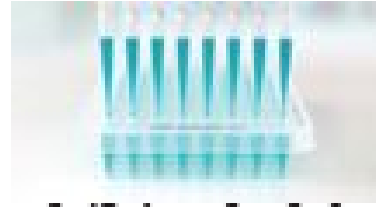

Providing Precise Solutions for your research. 